\title{
Glimpse into guts: overview of the feeding of larvae of tropical shorefishes
}

\author{
A. Sampey ${ }^{1,4}$, A. D. McKinnon' ${ }^{2}$, M. G. Meekan ${ }^{1}$ M. I. McCormick ${ }^{3,4}$ \\ ${ }^{1}$ Australian Institute of Marine Science, PO Box 40197 Casuarina MC, Northern Territory 0811, Australia \\ ${ }^{2}$ Australian Institute of Marine Science, PMB 3, Townsville MC, Queensland 4810, Australia \\ ${ }^{3}$ ARC Centre of Excellence for Coral Reef Studies, and ${ }^{4}$ School of Marine and Tropical Biology, James Cook University, \\ Townsville MC, Queensland 4810, Australia
}

\begin{abstract}
Knowledge of the diets of tropical fish larvae is limited to only a few taxa. Here, we describe the diets of 591 individuals from 50 families of tropical larval shorefishes collected off the Northwest Shelf of Australia $\left(21^{\circ} 49^{\prime} \mathrm{S}, 114^{\circ} 14^{\prime} \mathrm{E}\right)$, effectively doubling the number of families for which there is dietary data available. The diversity of prey items eaten differed significantly among families. The majority of fish larvae ate copepods but there were some interesting exceptions. Chaetodontids ate only chaetognaths, acanthurids and nemipterids ate appendicularians, and tetraodontids ate predominately non-copepod prey (44\% decapod larvae, $20 \%$ bivalves and $15 \%$ protists). Within the fish families that specialised on copepod prey there were marked differences in the types of copepod prey, with a clear preference shown for calanoid copepods, particularly small calanoids such as Bestiolina similis and Temora spp. Copepod communities in the area are foodlimited and we suggest that the ability of some larval fishes to feed on components of the microbial food web may be an important determinant of their success.
\end{abstract}

KEY WORDS: Diet - Larval fish · Feeding ecology · Prey selectivity - Calanoid copepods · Northwest Australia

Resale or republication not permitted without written consent of the publisher

\section{INTRODUCTION}

The importance of understanding the feeding ecology of marine fishes during the larval stage has been recognised for nearly a century (Hjort 1914). Variation in food availability is thought to have major effects on larval growth and survivorship and can ultimately determine the numbers of juvenile fish recruiting to adult populations (Houde 1987). To date, dietary studies have almost exclusively originated from temperate environments and have examined commercially important species such as Atlantic cod Gadus morhua, haddock Melanogrammus aeglifinus, and Atlantic herring Clupea harengus (from the orders Gadiformes and Clupeiformes). These studies show that larval fishes consume a wide range of zooplankton prey including phytoplankton, dinoflagellates, naked ciliates, tintinnids, rotifers, copepods, mollusc veligers, chaetognaths, appendicularia, and other fish larvae (Hunter 1981, Leis 1991). In contrast, relatively few studies have described the feeding ecology of larval fishes in tropical environments where perciform fishes dominate (Leis 1991). Taxonomic differences between these orders of fishes, which correspond to differences in body form (elongate vs. compact) and swimming abilities (fast vs. slow) for a given size of larvae (Leis et al. 1996, Fuiman \& Higgs 1997, Leis \& Carson-Ewart 1999, Fisher et al. 2000, Fisher \& Bellwood 2001, Leis \& McCormick 2002), as well as major differences in temperature and prey communities, may mean that generalisations from temperate studies are unlikely to apply to tropical larvae.

Net collections of ichthyoplankton from tropical waters are remarkably diverse and contain few larvae that can be identified to species (Leis 1993, Leis \& CarsonEwart 2000). When attempting to identify prey items in guts, problems of species diversity are greatly magnified. Consequently, dietary studies of tropical fish lar- 
vae have been limited to fewer than 35 species of shorefishes (Leis 1991, Østergaard et al. 2005), representing only a small fraction of the over 1000 species found on Indo-Pacific coral reefs (Lowe-McConnell 1987). Here, we attempted to provide a broad overview of the feeding of larvae of tropical shorefishes from shallow waters (20 to $100 \mathrm{~m}$ depth) off the North West Cape of Australia (hereafter NWC) by: (1) describing the diets of 50 families of larvae of tropical shorefishes; (2) exploring whether diets differed among taxa for (i) all taxa examined and (ii) copepod specialists, by identifying the copepod prey items at an increased level of taxonomic resolution; (3) examining whether family level differences in the diet still occur when spatiotemporal variation is removed, by examining the larvae collected in one net tow; and (4) calculating prey selectivity for some of the prey items of 7 co-occurring larval shorefishes. We aimed to generate testable hypotheses for future research about the nature of dietary specialisation, prey selectivity and the role of larval fish as predators in tropical planktonic ecosystems.

\section{MATERIALS AND METHODS}

Sample collection and processing. Ichthyoplankton were collected during cruises in the vicinity of the NWC $\left(21^{\circ} 49^{\prime} \mathrm{S}, 114^{\circ} 14^{\prime} \mathrm{E}\right)$ in the austral summers of 1997-98 and 1998-99. Sampling focused on a shallow inshore site ( $\mathrm{B}, \sim 20 \mathrm{~m}$ depth) located at the mouth of the Exmouth Gulf, and an offshore shelf break site (E, $\sim 100 \mathrm{~m}$ depth); an additional inshore site (TB, $16 \mathrm{~m}$ depth) was sampled further north on the shelf near Thevenard Island in the second summer (see Fig. 1 in Sampey et al. 2004). Oblique tows of Bongo nets $(0.8 \mathrm{~m}$ net diameter, $500 \mu \mathrm{m}$ mesh) to $\sim 16 \mathrm{~m}$ depth were used to collect larvae at both sites. To ensure full guts, sampling occurred near dusk, as larval fish are visual predators (Blaxter 1986) with peaks in feeding occurring at dawn and dusk (Last 1980, Young \& Davis 1990, McLaren \& Avendano 1995, McLaren et al. 1997). For full details of sampling techniques see Sampey et al. (2004). Zooplankton was sampled using vertically towed nets $(0.5 \mathrm{~m}$ diameter, modified WP-2 net, $73 \mu \mathrm{m}$ mesh; see Meekan et al. 2003).

Larval fishes were sorted into recognisable taxa and identified to the lowest taxonomic level possible (usually family). Taxa were initially selected for gut analysis based on abundance, with up to 20 ind. of particular taxa targeted wherever possible from the same sample. Subsequently, fish were analysed based on whether they could be considered to be reef fishes (sensu Leis \& Carson-Ewart 2000). Standard length (SL) and mandible length (ML) were measured with an ocular micrometer. The guts were carefully excised from the body wall with electrolytically sharpened tungsten needles and placed onto a microscope slide into a drop of glycerin. This assists dissection by dampening particle movement and aids the detection of food items due to its clearing properties (Arthur 1976). A subjective measure of gut fullness (GF) ([1] empty; [2] 1/4; [3] 1/2; [4] 3/4; and [5] full) and the state of digestion of the contents ([1] intact prey; [2] exoskeleton starting to separate from the body; and [3] exoskeleton or bits only) was recorded (Young \& Davis 1990). The guts were then teased apart and the contents were identified to the lowest taxonomic level possible and enumerated.

Data analysis. Prey items were pooled into 21 categories to display broad trends. For each prey category an index of relative importance (IRI) (Sassa \& Kawaguchi 2004) was calculated:

$$
\mathrm{IRI}=\% \mathrm{~N} \times \% \mathrm{FO}
$$

where $\% \mathrm{~N}$ for each prey category was the number of times a particular prey category occurred as a percentage of the total number of prey categories found for that fish taxon and \%FO was the frequency of occurrence of a particular prey category expressed as a percentage of the total number of stomachs examined for each fish family (McKinnon et al. 2002, Sassa \& Kawaguchi 2004). We considered prey categories that had an IRI $>1000$ to be major dietary components for that family, those with an IRI between 100 to 1000 to be moderate components and $<100$ to be minor components.

Data analysis was conducted in PRIMER v6 beta and Statistica 6.1 using the results from non-empty guts. We used ANOVA on the Shannon-Wiener diversity index $\left(H^{\prime}\right)$, which was calculated for each fish in PRIMER, to test for differences in prey diversity among fish families. The multivariate analytical approach examined data at various scales of prey identification and spatio-temporal occurrence of fish larvae, to elucidate relationships among the fish families and their prey. We first removed unidentified prey as a category $(\sim 3 \%$ of total prey items) as these occurred across many families and thus did not contribute to our understanding of the dietary difference among families. An average of each prey category per family was calculated and a data matrix constructed by considering the families as samples and the pooled prey categories as variables (46 families by 20 prey categories). The numbers of prey in a larva's gut will be influenced by the size of the gut and this will differ between taxa. To compensate for this, we first standardised the data by converting the prey to a percentage composition of the total prey categories for each fish family. A similarity matrix was then produced using the Bray-Curtis distance measure as it is insensitive to zero values while at the same time preserving the influence of abundant prey items. Group averaged clustering and non-metric 
multi-dimensional scaling (nMDS) analyses were then performed (minimum of 25 iterations) to produce dendrograms and 2-dimensional ordinations. The adequacy of the nMDS was assessed using stress values. A stress of $<0.1$ provides a good ordination, a stress of $<0.2$ provides a useful ordination and stress values $>0.2$ need to be examined at higher dimensions to avoid misinterpretation (Clarke \& Warwick 2000). Generally, the 3-dimensional plots of the datasets provided a better representation of relationships (i.e. lower stress values). However, these were best when viewed on the computer screen where they could be manipulated, but translated poorly to print and were difficult to plot with cluster analyses. Consequently, we chose to display only 2-dimensional plots, which followed the same trends as the 3-dimensional plots. We examined the cluster and nMDS plots to see what groupings formed and then set a cut-off of $30 \%$ similarity (Clarke \& Warwick 2000). SIMPER (similarity percentages) was then used to determine the prey categories that had contributed to the groupings observed from the cluster and nMDS analyses.

To provide a more detailed description of the taxa of copepods being eaten, we repeated these analyses on a subset of the data for families of fish larvae that fed predominately on these prey. We removed both unidentified prey and copepod fragments and identified copepod adults to genus and juveniles to order, while non-copepod preys were lumped into one category (data matrix of 27 prey categories for 38 families of larval fishes).

The previous analyses considered larvae from a variety of sampling sites and times, so the differences recorded among families could have been confounded by spatio-temporal differences in the prey encountered. To examine if family level differences were still observed in the diets of co-occurring larvae, we repeated the analyses on a subset of larvae that were all collected in one sample from an inshore site (B, $\sim 20 \mathrm{~m}$ depth) on 17 February 1999. For these we used similar prey categories to those in the copepod analysis, although not all of these prey categories occurred in this sample (data matrix of 11 families and 17 prey categories). Finally, prey selectivity was assessed for these same co-occurring larvae using Chesson's $\alpha$ index (Chesson 1978):

$$
\alpha=\left(r_{i} / p_{i}\right)\left(\sum r_{i} / p_{i}\right)^{-1}(i=1, \ldots, m)
$$

where $r_{i}$ and $p_{i}$ are the proportion of prey category $i$ in the diet and in the water column respectively and $m$ is the number of prey categories. Neutral preference occurs at $1 / \mathrm{m}$. The proportion of prey in the water column was estimated from the average of zooplankton densities (number $\mathrm{m}^{-3}$ ) for 2 vertical net tows, while the proportion of prey categories in the diet was esti- mated using an average count of prey categories that occurred in guts. The sub-sampling procedures for counting zooplankton samples meant that zooplankton that occurred in densities $<6 \mathrm{~m}^{-3}$ in the field may not have been detected in the samples, despite being present at the sampling location. Prior to calculation of $\alpha$, prey categories not present in the guts (e.g. Acrocalanus gibber) and prey categories not recorded from the water column, whether because they were potentially rare (e.g. Clausocalanus farrani, Corycaeus asiaticus, Oithona rigida, Parvocalanus sp., Pseudodiaptomus sp.), the levels of identification/groupings differed (e.g. copepod nauplii, Oithona spp. and poecilostome juveniles), or because they were not counted as part of the zooplankton sampling data (e.g. Dynophysis), were excluded. This limits our conclusions to the relative selectivity of some components of the plankton. We considered $\alpha>4$ to indicate high selectivity for a particular prey category, $4>\alpha>1$ to indicate moderate selectivity and $\alpha<1$ to indicate low selectivity. To look in more detail at differences within a family the gobiids were able to be split into 2 groups, Gobiidae mixed spp., which were all of an elongate body form, and Gobiidae sp. 6, which was a deep bodied darkly pigmented species. Prey selectivity was assessed for 6 families of larval fish ( 7 taxa) ( $\mathrm{n}>5$ individuals).

\section{RESULTS}

\section{Fish lengths, gut fullness and digestion ratings}

We examined whole gut contents of 591 individuals from 50 taxa of predominately early post-flexion larvae of $\sim 4 \mathrm{~mm}$ SL (Table 1). Mean SL ranged from $3 \mathrm{~mm}$ (callionymids, aploactinids, carangids, leiognathids, and serranids) to $25 \mathrm{~mm}$ (fistulariids). Mean ML ranged from $0.3 \mathrm{~mm}$ (synodontids) to $1.6 \mathrm{~mm}$ (fistulariids). Mean GF ranged from empty $(1 \pm 0$, engraulids, berycids, and scarids) to full ( $5 \pm 0$, aploactinids, opistognathids, pomacanthids, priacanthids, and samarids), i.e. all individuals examined in these families recorded empty $(\mathrm{GF}=1)$ or full $(\mathrm{GF}=5)$ guts so there is no variation around the mean result. The majority of prey items were in an advanced stage of digestion (digestion rating $>2$ ); even in those individuals whose guts also contained intact prey items.

\section{Prey composition of diets}

Prey diversity, measured as the Shannon diversity in$\operatorname{dex}\left(H^{\prime}\right)$, differed among families (MS $=0.9, F=6.1$, df $=46, \mathrm{p}<0.05)$ and was highest for siganids and labrids (2.1 and 2 respectively, Table 1 ). Seven families re- 
Table 1. Families of larval fishes, collected with plankton nets near the North West Cape of Australia (NWC) $\left(21^{\circ} 49^{\prime} \mathrm{S}, 114^{\circ} 14^{\prime} \mathrm{E}\right)$, used for gut content analysis. TGE: Total guts examined; EG: number of empty guts; SL and ML: standard and mandibular length, respectively; GF: Gut fullness (1: empty; $2: 1 / 4 ; 3: 1 / 2 ; 4: 3 / 4 ; 5$ : full); $H^{\prime}$ : Shannon-Wiener diversity index, $\left(\log _{\mathrm{e}}\right)$; ST: Spatiotemporal collection details (B: inshore station B; E: offshore station E; T: inshore station TB; O: October; N: November; D: December; F: February; 7: 1997; 8: 1998; 9: 1999) (see Sampey et al. 2004 for further collection details). Stage: Larval development stage (Pe: Pre-flexion; F: Flexion; Po: Post-flexion). SL, ML, GF given as mean $\pm \mathrm{SD}$

\begin{tabular}{|c|c|c|c|c|c|c|c|c|c|c|}
\hline No. & Family & Common name & TGE & EG & $\mathrm{SL}(\mathrm{mm})$ & $\mathrm{ML}(\mathrm{mm})$ & GF & $H^{\prime}$ & $\mathrm{ST}$ & Stage \\
\hline & Clupeiformes & & & & & & & & & \\
\hline 1 & Clupeidae & herrings, sardines, sprats & 20 & 12 & $11 \pm 2$ & $0.7 \pm 0.1$ & $1 \pm 1$ & 0.3 & BD7 & Po \\
\hline 2 & $\begin{array}{l}\text { Engraulidae } \\
\text { Aulopiformes }\end{array}$ & anchovies & 20 & 20 & $7 \pm 1$ & $0.8 \pm 0.2$ & $1 \pm 0$ & - & TD8 & Po \\
\hline 3 & $\begin{array}{l}\text { Synodontidae } \\
\text { Ophidiiformes }\end{array}$ & lizardfishes & 6 & 5 & $6 \pm 4$ & $0.3 \pm 0.1$ & $1 \pm 1$ & 0.7 & EF8EN7 & PeFPo \\
\hline 4 & $\begin{array}{l}\text { Ophidiidae } \\
\text { Gobiesociformes }\end{array}$ & cusk eels & 3 & 1 & $9 \pm 7$ & $1.2 \pm 0.7$ & $3 \pm 2$ & 0.8 & END7BD8 & FPo \\
\hline 5 & Callionymidae & dragonets & $21^{\mathrm{a}}$ & 0 & $3 \pm 1$ & - & $3 \pm 1$ & 1.5 & BF9 & Po \\
\hline 6 & $\begin{array}{l}\text { Gobiesocidae } \\
\text { Beryciformes }\end{array}$ & clingfishes & 2 & 0 & $5 \pm 3$ & $0.7 \pm 0$ & $4 \pm 1$ & 0.2 & EF8BF8 & PePo \\
\hline 7 & Berycidae & redfishes & 1 & 1 & $5 \pm 0$ & $1 \pm 0$ & $1 \pm 0$ & - & BN7 & Po \\
\hline 8 & $\begin{array}{l}\text { Holocentridae } \\
\text { Gasterosteiformes }\end{array}$ & squirrelfishes & 8 & 0 & $5 \pm 1$ & $0.8 \pm 0.1$ & $3 \pm 1$ & 1.2 & EF9 & PeFPo \\
\hline 9 & Centriscidae & razorfishes & 5 & 1 & $5 \pm 6$ & $0.7 \pm 0.1$ & $3 \pm 1$ & 1.1 & BF9TD8 & PePo \\
\hline 10 & Fistulariidae & flutemouths & 7 & 0 & $25 \pm 22$ & $1.6 \pm 1$ & $4 \pm 1$ & 1.5 & BN7EN8F9 & $\mathrm{PePo}$ \\
\hline 11 & Solenostomidae & ghost pipefishes & 1 & 0 & $4 \pm 0$ & $0.4 \pm 0$ & $4 \pm 0$ & 0 & TN8 & $\mathrm{Pe}$ \\
\hline 12 & $\begin{array}{l}\text { Syngnathidae } \\
\text { Scorpaeniformes }\end{array}$ & seahorses \& pipefishes & 24 & 1 & $22 \pm 10$ & $0.7 \pm 0.2$ & $4 \pm 1$ & 0.9 & BD7TND8 & $\mathrm{Po}$ \\
\hline 13 & Aploactinidae & velvetfishes & $4^{\mathrm{a}}$ & 0 & $3 \pm 0$ & $0.5 \pm 0$ & $5 \pm 0$ & 0.9 & BF9 & Po \\
\hline 14 & Scorpaenidae & scorpionfishes & 10 & 0 & $6 \pm 2$ & $1 \pm 0.6$ & $4 \pm 1$ & 1.1 & BN7F9ED7NF8TD8 & PePo \\
\hline 15 & $\begin{array}{l}\text { Platycephalidae } \\
\text { Perciformes }\end{array}$ & flatheads & $17^{\mathrm{a}(4)}$ & 0 & $5 \pm 1$ & $1 \pm 0.3$ & $4 \pm 1$ & 1.2 & BND7F8F9ED7TD8 & PeFPo \\
\hline 16 & Acanthuridae & surgeonfish & 1 & 0 & $5 \pm 0$ & $0.6 \pm 0$ & $2 \pm 0$ & 0 & EF8 & Po \\
\hline 17 & Apogonidae & cardinalfishes & 10 & 0 & $5 \pm 1$ & $0.9 \pm 0.2$ & $3 \pm 1$ & 1.5 & ED78 & PePo \\
\hline 18 & Blenniidae & blennies & 10 & 0 & $5 \pm 1$ & $0.9 \pm 0.1$ & $4 \pm 1$ & 1.4 & ED8 & PeFPo \\
\hline 19 & Carangidae & jacks, trevallies & $3^{\mathrm{a}}$ & 0 & $3 \pm 1$ & $0.6 \pm 0.5$ & $5 \pm 1$ & 1.2 & BF9 & Po \\
\hline 20 & Chaetodontidae & butterflyfishes & 2 & 0 & $6 \pm 0$ & $0.9 \pm 0.2$ & $4 \pm 1$ & 0 & BN7TD8 & Po \\
\hline 21 & Cirrhitidae & hawkfishes & 1 & 0 & $5 \pm 0$ & $1 \pm 0$ & $4 \pm 0$ & 0 & BF9 & Po \\
\hline 22 & Gobiidae & gobies & $39^{\mathrm{a}}$ & 1 & $5 \pm 1$ & $0.6 \pm 0.2$ & $3 \pm 1$ & 1.8 & BF9 & Po \\
\hline 23 & Haemulidae & sweetlips, grunts & 12 & 0 & $4 \pm 1$ & $1 \pm 0.1$ & $4 \pm 1$ & 1.3 & BON7D8TD8ED7 & FPo \\
\hline 24 & Labridae & wrasses & 14 & 3 & $7 \pm 2$ & $1 \pm 0.2$ & $3 \pm 1$ & 2 & BN7D8EOND7 & Po \\
\hline 25 & Leiognathidae & ponyfishes & $20^{\mathrm{a}}$ & 4 & $3 \pm 0$ & $0.5 \pm 0.1$ & $2 \pm 1$ & 1.1 & BF9 & FPo \\
\hline 26 & Lethrinidae & emperors & 20 & 2 & $4 \pm 3$ & $0.6 \pm 0.4$ & $4 \pm 1$ & 1.3 & BN7 & Po \\
\hline 27 & Lutjanidae & snappers \& fusiliers & 20 & 0 & $5 \pm 1$ & $0.8 \pm 0.2$ & $4 \pm 1$ & 1.8 & EF8BF8EF9 & PePo \\
\hline 28 & Microdesmidae & wormfishes \& dartfishes & 20 & 3 & $9 \pm 1$ & $0.9 \pm 0.1$ & $2 \pm 1$ & 1.2 & EF8 & Po \\
\hline 29 & Mullidae & goatfishes & 15 & 0 & $4 \pm 0$ & $0.6 \pm 0.1$ & $4 \pm 1$ & 1.5 & ED7F89BN78D7 & FPo \\
\hline 30 & Nemipteridae & threadfin \& monocle breams & 13 & 2 & $4 \pm 1$ & $0.7 \pm 0.2$ & $3 \pm 1$ & 0 & BF9 & PeFPo \\
\hline 31 & Opistognathidae & jawfishes & $1^{\mathrm{a}}$ & 0 & $4 \pm 0$ & $0.5 \pm 0$ & $5 \pm 0$ & 0 & BF9 & Po \\
\hline 32 & Pinguipedidae & grubfishes \& sandfishes & $20^{\mathrm{a}}$ & 0 & $4 \pm 1$ & $0.8 \pm 0.1$ & $4 \pm 1$ & 1.8 & BF9 & Po \\
\hline 33 & Pomacanthidae & angelfishes & 5 & 0 & $5 \pm 2$ & $1 \pm 0.2$ & $5 \pm 0$ & 1.2 & BF89TD8 & PoF \\
\hline 34 & Pomacentridae & damselfishes & 12 & 0 & $8 \pm 1$ & $1.4 \pm 0.2$ & $4 \pm 1$ & 1.2 & EN78 & Po \\
\hline 35 & Priacanthidae & bigeyes & 10 & 0 & $5 \pm 2$ & $1 \pm 0.5$ & $5 \pm 0$ & 1.7 & BN7F8EOD7F9 & PeFPo \\
\hline 36 & Pseudochromidae & dottybacks \& eelblennies & 10 & 0 & $6 \pm 2$ & $1.1 \pm 0.3$ & $3 \pm 1$ & 0.8 & BN7END8 & $\mathrm{PePo}$ \\
\hline 37 & Scaridae & parrotfishes & 2 & 2 & $10 \pm 2$ & $0.9 \pm 0.1$ & $1 \pm 0$ & - & BN7EO8 & Po \\
\hline 38 & Scombridae & tunas and mackerels & 20 & 0 & $5 \pm 1$ & $1 \pm 0.2$ & $4 \pm 8$ & 1 & EF8 & PeFPo \\
\hline 39 & Serranidae & groupers \& reef basses & 20 & 0 & $3 \pm 0$ & $0.5 \pm 0.1$ & $5 \pm 1$ & 1.3 & BN7 & PePo \\
\hline 40 & Siganidae & rabbitfishes & 6 & 0 & $9 \pm 5$ & $0.7 \pm 0.1$ & $4 \pm 0$ & 2.1 & BF9TN8 & Po \\
\hline 41 & Sphyraenidae & barracudas & 20 & 1 & $6 \pm 1$ & $1.1 \pm 0.3$ & $3 \pm 1$ & 1.1 & BND7N8EN7DF8TD8 & PePo \\
\hline 42 & Terapontidae & grunters & 20 & 0 & $4 \pm 0$ & $0.7 \pm 0.1$ & $4 \pm 1$ & 0.5 & BN8 & Po \\
\hline 43 & Trichonotidae & sand divers & 4 & 2 & $8 \pm 4$ & $1 \pm 0.4$ & $2 \pm 1$ & 0.7 & BF8EF8TD8 & PePo \\
\hline 44 & Tripterygiidae & triplefins & 10 & 1 & $7 \pm 2$ & $0.9 \pm 0.2$ & $3 \pm 1$ & 1.8 & BON7D8F9ED8 & PePo \\
\hline 45 & $\begin{array}{l}\text { Uranoscopidae } \\
\text { Pleuronectiformes }\end{array}$ & stargazers & 1 & 0 & $4 \pm 0$ & $1 \pm 0$ & $3 \pm 0$ & 0 & $\mathrm{EO} 7$ & Po \\
\hline 46 & Bothidae & left-eye flounders & $22^{\mathrm{a}(2)}$ & $11^{\mathrm{a}(2)}$ & $9 \pm 3$ & $0.8 \pm 0.4$ & $2 \pm 1$ & 1.1 & BN7F9 & Po \\
\hline 47 & Cynoglossidae & tongue soles & $20^{\mathrm{a}}$ & 0 & $5 \pm 2$ & $0.5 \pm 0.2$ & $4 \pm 1$ & 1.3 & BF9 & Po \\
\hline 48 & $\begin{array}{l}\text { Samaridae } \\
\text { Tetraodontiformes }\end{array}$ & crested flounders & $1^{\mathrm{a}}$ & 0 & $4 \pm 0$ & $0.8 \pm 0$ & $5 \pm 0$ & 0.6 & BF9 & Po \\
\hline 49 & Monacanthidae & leatherjackets \& filefishes & $28^{\mathrm{a}(8)}$ & 6 & $5 \pm 3$ & $0.4 \pm 0.2$ & $3 \pm 1$ & 1.6 & BF9 & Po \\
\hline 50 & Tetraodontidae & puffers & 11 & 0 & $4 \pm 1$ & $0.6 \pm 0.2$ & $4 \pm 1$ & 1.3 & BN7D8EN8TD8 & PeFPo \\
\hline
\end{tabular}




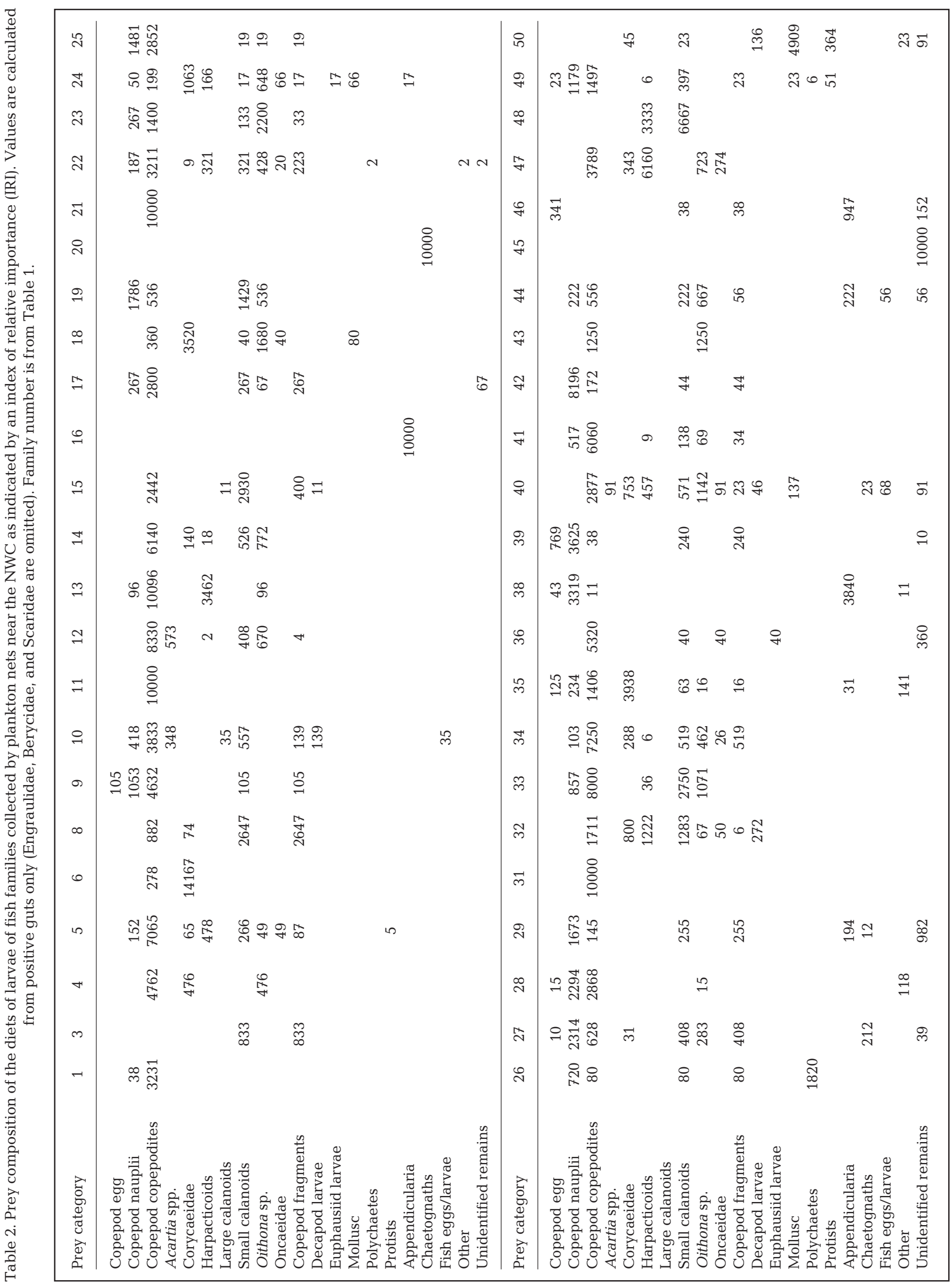


corded an index of relative importance (IRI) of 10000 as only one prey type was recorded in all of the larvae examined (Table 2). These larvae included nemipterids and acanthurids, which preyed upon appendicularians; chaetodontids, which ate chaetognaths; and cirrhitids, opistognathids and solenostomids, which ate copepodites. These findings are limited by the examination of only one larva for each of these families, except for nemipterids (13 ind.) and chaetodontids ( 2 ind.).

Copepods were major prey items for the majority of families. Copepod juveniles were the most important dietary component for 34 families of larvae (copepodites and nauplii, 24 and 10 families respectively, Table 2). Adult copepods were major prey items for many families; e.g. Corycaeidae Corycaeus spp. and Farranula spp. for gobiesocids, blenniids, labrids and priacanthids. Only 2 families consumed non-copepod prey as a major component of their diet; tetraodontids ate molluscs (mostly gastropods) and lethrinids (Lethrinus sp.) ate polychaetes (IRI 4909 and 1829 respectively). The only other larvae to eat polychaetes were monacanthids and gobiids, but only as a minor part of their diet (IRI 51 and 2 respectively). Gastropods were a minor dietary component of blennids and labrids (IRI 80 and 66) and bivalves for siganids and monacanthids (IRI 137 and 23).

A generalist feeding strategy was indicated for only 3 families, where only moderate values (IRI < 1000) were recorded for a particular type of prey. These included bothids, which preyed on appendicularia (IRI 947); synodontids, which preyed on small calanoids and copepod fragments (IRI 833 for both prey groups); and tripterygiids, which preyed on Oithona spp. (IRI 667), copepod juveniles (IRI 556), copepod nauplii, small calanoids and appendicularia (all IRI 222).

Some prey species were only eaten as minor components of diets. Large calanoids (Undinula vulgaris and Euchaeta spp.) were eaten by fistulariids and platycephalids (IRI 35 and 11 respectively). Fish eggs were eaten by siganids and tripterygiids and a fish larva (a goby) was eaten by the largest larva examined, a fistulariid of $65 \mathrm{~mm}$ (IRI 68, 56, and 35 respectively). Protists (Dynophysis sp. and a radiolarian) were recorded from callionymids, monacanthids and tetraodontids (IRI 5, 51 and 363).

\section{Dietary differences among fish families}

Clustering and nMDS analyses of all families produced 6 groups at $30 \%$ similarity (Fig. 1). Two groups were formed by families that ate only one prey type: chaetodontids (Family 20), which ate chaetognaths (Group 1), acanthurids (Family 16) and nemipterids (Family 30), which ate appendicularians (Group 2).
Group 3 was formed by tetraodontids (Family 50), which ate a mixed diet of mainly non-copepod prey including decapod larvae (44\%), bivalves $(20 \%)$ and protists (15\%). Group 4 was composed of gobiesocids (Family 6) that preyed on corycaeid copepods (85\% of diet) and copepod juveniles (15\%, mainly Oithona sp.). Bothids (Family 46), samarids (Family 48) and synodontids (Family 3) (Group 5) had the most diverse diets. Bothids were closer to Group 2 due to a high proportion of appendicularian prey but also near Group 6 due to the incidence of copepods in their diet. Synodontids and samarids were plotted closer together as they both ate small calanoids. The remaining families formed a large group (Group 6) that specialised on copepod prey including copepod copepodites and nauplii (56\%), calanoid copepods (13\%), Oithona sp. (10\%), harpacticoid and corycaeid copepods (each contributing $5 \%$ of total prey categories).

The majority of the larvae examined fed on copepods (Group 6, Fig. 1), but the types of copepods eaten differed among taxa. A more detailed examination of this group formed only 5 groups (Groups 7 to 11) at $30 \%$ similarity (Fig. 2). Trichonotids (Family 43), solenostomids (Family 11) and cirrhitids (Family 21) (Group 7) ate predominately Oithona sp. (88\% of diet, mostly juveniles). Holocentrids (Family 8, Group 8) ate copepod juveniles (mostly poecilostomes, 33\%, and calanoids, 22\%) and copepod adults (Clausocalanus spp. and Farranula spp., each $22 \%$ ). Lethrinids (Family 26), serranids (Family 3), mullids (Family 29), terapontids (Family 42), priacanthids (Family 35) and scombrids (Family 38) (Group 9) specialised on copepod nauplii ( $47 \%$ contribution to the group). The 25 fish families that composed Group 10 ate calanoid copepodites $(20 \%)$, Oithona sp. $(21 \%)$, calanoid copepods $(15 \%)$ and copepod juveniles $(14 \%)$. Monacanthids (Family 49), carangids (Family 19), and platycephalids (Family 15) (Group 11) ate calanoid copepods (44\%, mostly Temora spp.), Oithonidae (18\%, mostly Oithona juveniles) and copepod juveniles (19\%). The families in this group appear to have little in common with each other and in the 3-dimensional plots Group 11 sits above the others in a vertical plane, but this detail has been lost in the 2-dimensional plots.

The analysis of co-occurring families (from inshore site B, 17 February 1999) produced a dendrogram that split these into 3 groups (Groups 12 to 14 ) at $30 \%$ similarity (Fig. 3). Samarids (Family 48, Group 12, 1 ind.) ate Temora spp. (67\%) and Euterpina acutifrons (33\%). One opistognathid (Family 31, Group 13) ate calanoid juveniles. Group 14 can be further broken down into 3 groups at the $40 \%$ similarity. Group 14a consisted of aploactinids (Family 13, 4 ind.), callionymids (Family 5, 21 ind.), gobiids (Family 22, 39 ind.), cynoglossids (Family 47, Cynoglossus sp., 20 ind.) and 
a
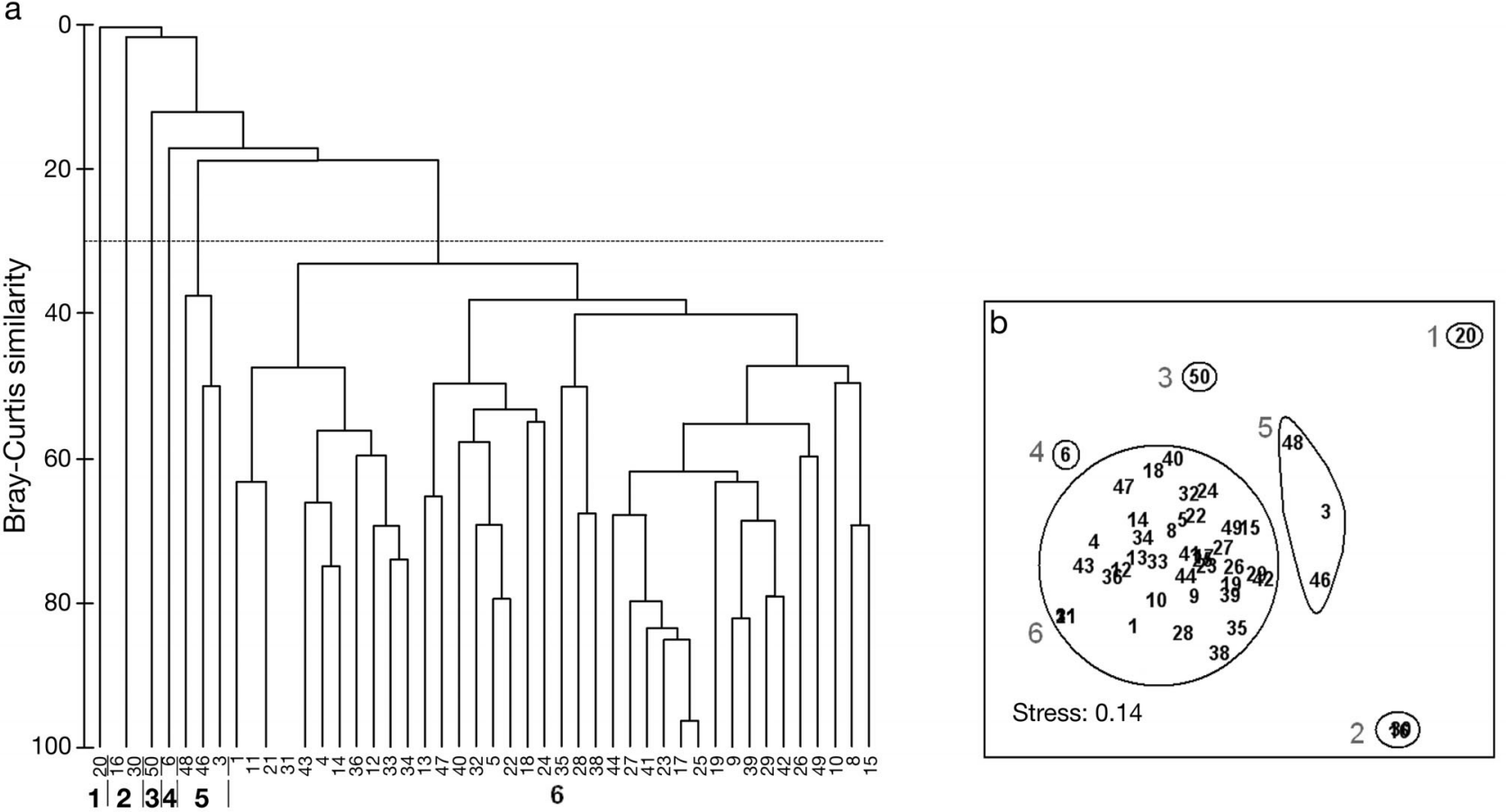

C

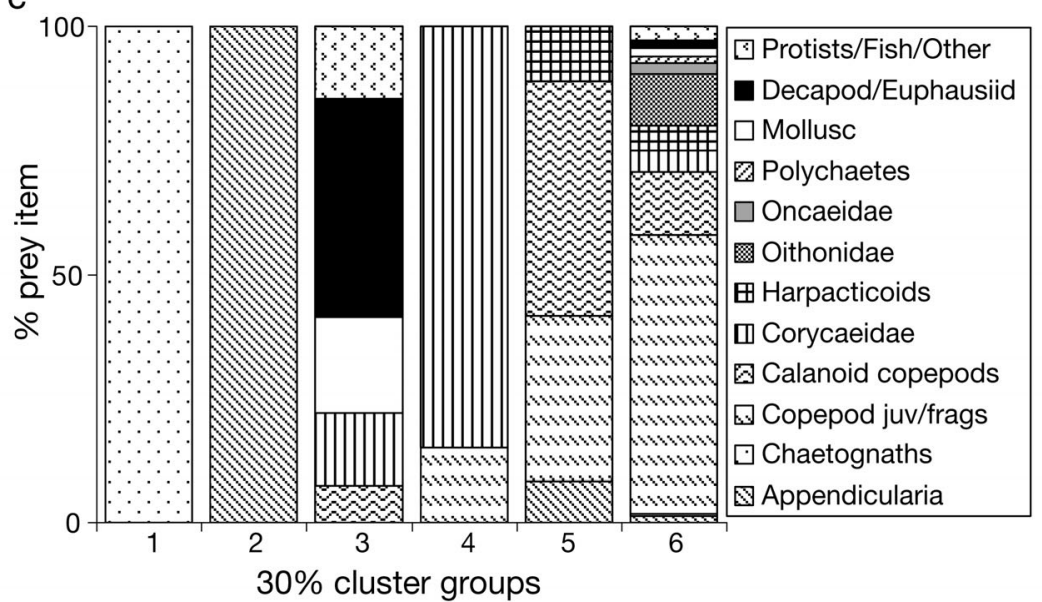

Fig. 1. (a) Dendrogram and (b) 2-dimensional ordination generated from a similarity matrix of 20 prey categories from 47 families of larval fishes collected by plankton nets near the North West Cape of Australia (NWC). Each fish family is identified by the family number taken from Table 1. Diets of families closer together are more similar than those further apart. Clusters 1 to 6 were identified at the $30 \%$ similarity: (c) prey composition of these 6 clusters

pinguipedids (Family 32, 20 ind.). This group ate a mixed diet of harpacticoids $(22.5 \%$, Euterpina acutifrons and Microsetella spp.), Oithona spp. (18\%, adults and copepodites), copepod nauplii and copepodites $(15 \%)$, and calanoid copepods $(15 \%)$. These larvae were the only predators of Bestiolina similis and Pseudodiaptomus spp., although these were only consumed in small amounts (3\% and $1.5 \%$ of diet respectively).

Carangids (Family 19, Group 14b, 3 ind.) ate a mixed diet including copepod nauplii (26\%), Parvocalanus spp. $(23 \%)$, Oithona spp. (adults and copepodites, $16 \%)$, Temora spp. (19.5\%), harpacticoids (8\%) and calanoid juveniles (8\%). Platycephalids (Family 15, 4 ind.), leiognathids (Family 25, 20 ind.) and monacan- thids (Family 49, 8 ind.) (Group 14c) also ate a mixed diet including Clausocalanus farrani (23\%), calanoid juveniles (19\%), Oithona spp. (adults and copepodites, $14 \%)$, copepod nauplii $(13 \%)$, Temora spp. (13\%). Non-copepod prey (12\%) formed the diet of monacanthids (molluscs, polychaetes and protists) and platycephalids (decapod larvae).

\section{Zooplankton abundance and prey selectivity for co-occurring larvae}

Analysis of zooplankton and fish larvae sampled at the same station showed that cyclopoid juveniles were the most abundant prey category (260000 per $100 \mathrm{~m}^{3}$ ) 

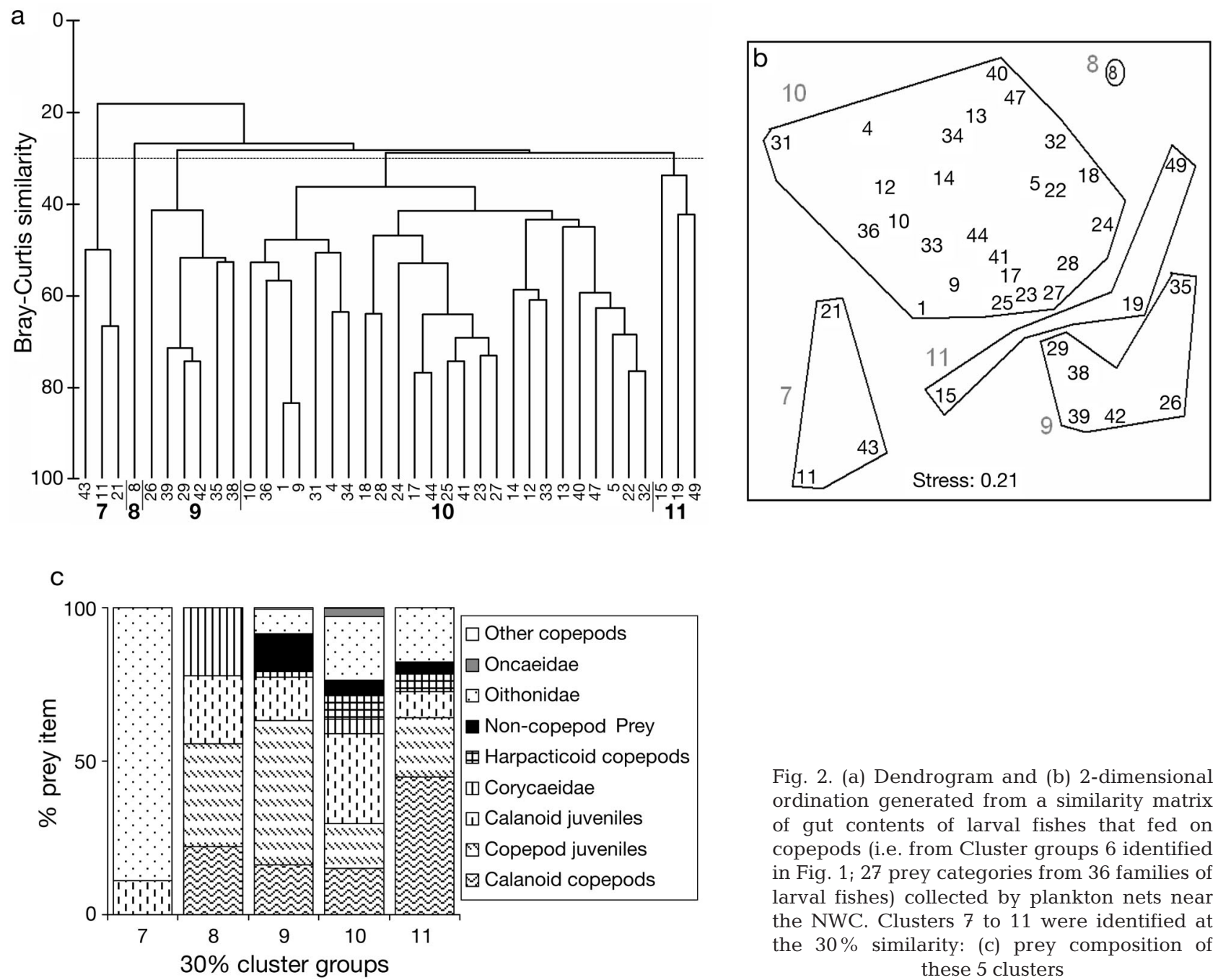

Fig. 2. (a) Dendrogram and (b) 2-dimensional ordination generated from a similarity matrix of gut contents of larval fishes that fed on copepods (i.e. from Cluster groups 6 identified in Fig. 1; 27 prey categories from 36 families of larval fishes) collected by plankton nets near the NWC. Clusters 7 to 11 were identified at the $30 \%$ similarity: (c) prey composition of these 5 clusters

and Acrocalanus gibber and Corycaeus andrewsi were the least abundant (600 per $100 \mathrm{~m}$ ) (Table 3). Callionymids were the most abundant larvae (40 per 100 $\mathrm{m}^{3}$ ) and samarids and opistognathids the least abundant $\left(0.2\right.$ per $\left.100 \mathrm{~m}^{3}\right)$. Some prey taxa (e.g. Clausocalanus farrani), which were eaten by some larvae, could not be included in the prey selectivity analysis as they were not present in sufficient concentrations to show in the sorted fraction of the zooplankton sample. A total of 17 prey categories were assessed for selectivity for 7 taxa of larval fishes.

Larvae of shorefish families differed in their pattern of selectivity. Some prey were strongly selected, such as Oithona attenuata $(\alpha=1.6)$ by leiognathids (present in $45 \%$ of guts, but $4 \%$ of available prey; Figs. $4 \& 5$, Table 3). Other preys were avoided, such as harpacticoid juveniles by Cynoglossus sp. (6\% of prey items in guts but $24 \%$ of prey in the environment). Bestiolina similis was rare in the water column $(0.5 \%)$ but a highly preferred prey item for two families (Gobiidae, both mixed species, $20 \%, \alpha=6.8$, and Goby sp. 6, $9 \%$, $\alpha=2.7$, Pinguipedidae, $7 \%, \alpha=2.1$; Figs. $4 \& 5$, Table 3). Pinguipedids showed high selectivity for both Temora sp. $(15 \%, \alpha=5.6)$ and Corycaeus andrewsi $(7 \%, \alpha=5.3)$, and these prey items were also rare in the water column $(0.4 \%$ and $0.2 \%$ respectively). Monacanthids showed a moderate selectivity for polychaetes $(33 \%, \alpha=2.3)$, which were another rare prey category ( $2 \%$ of available prey).

\section{DISCUSSION}

We have described the diets of 50 families of tropical larval shorefishes from the NWC, effectively doubling the number of families for which we now have some knowledge of prey types and feeding patterns. Copepods have been shown to be the main prey item of lar- 


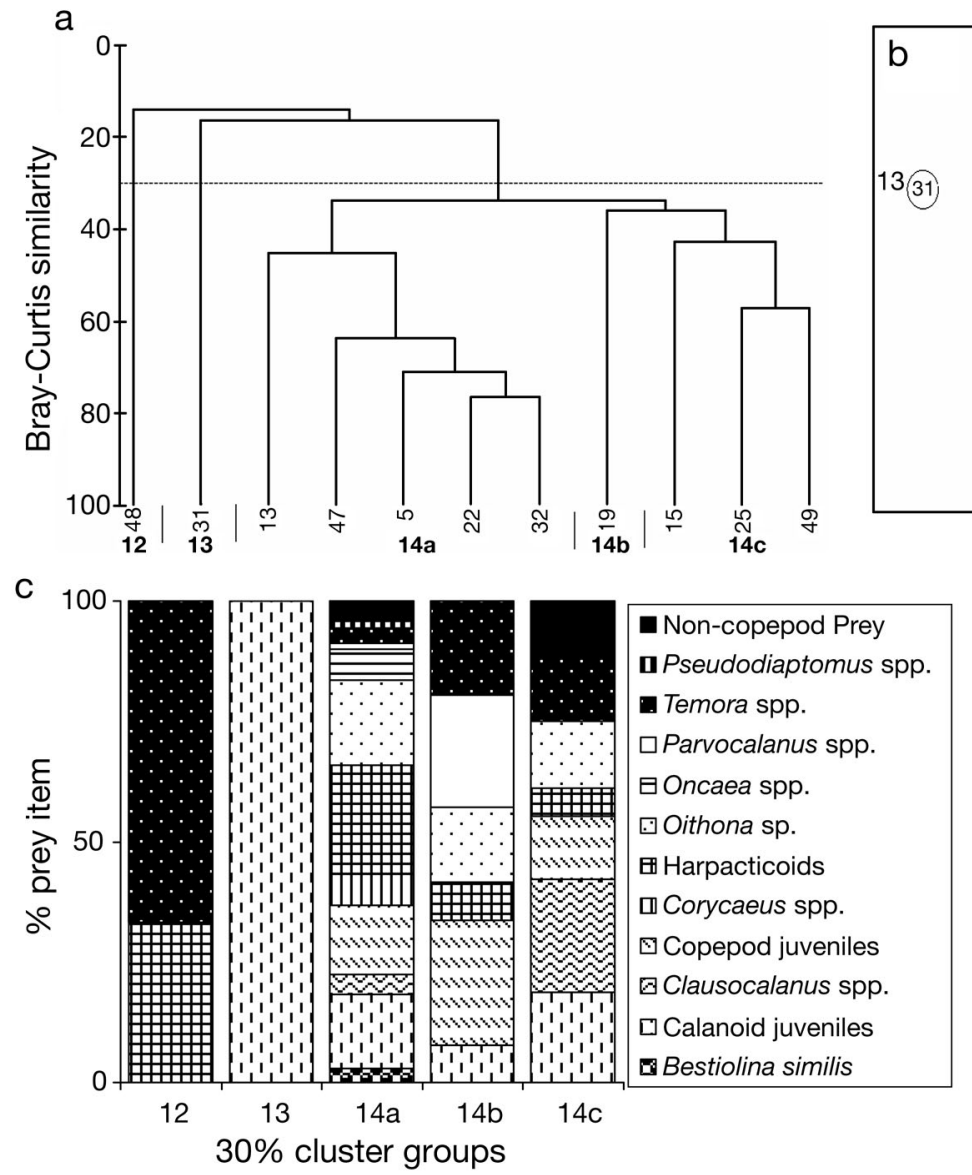

Fig. 3. (a) Dendrogram and (b) 2dimensional ordination generated from a similarity matrix of cooccurring larvae from one sample collected by plankton nets on the NWC (29 prey categories from 11 families of larval fishes). Clusters 12 to 14 were identified at the $30 \%$ similarity: (c) prey composition of these groups val fishes in temperate waters (Hunter 1981). Our study reinforces the conclusion of previous work (Leis 1991; Østergaard 2005) that this is also the case in tropical systems. Clupeids, apogonids, blennids, gobiids, haemulids, pomacentrids, scorpaenids, scarids and carangids specialise on copepod prey (Table 4). Moreover, the orders of copepods eaten by some families were remarkably consistent across studies e.g. callionymids ate cyclopoid copepods and scorpaenids ate calanoid and corycaeid copepods (Table 4). There were some differences; carangids sampled in Hawaii ate predominately Oithona spp., whereas those from the Andaman Sea and NWC showed a preference for calanoid copepods. This may be due to either interspecific differences in morphology, physiology and behaviour of larvae or could simply reflect a variation in the spatiotemporal occurrence of the prey types among locations and habitat types sampled by each study (bays, coastal or oceanic waters).

Fish larvae from over 76 families occurred in our collections (Sampey et al. 2004). We have had to restrict our examination to the 50 families for which there was suitable material available, and to cover the range of taxonomic diversity we have had to compro- mise the number of replicate individuals examined within each family. Consequently our data do not capture the full range of variability of feeding by larvae within a family, either spatiotemporal (daily, monthly, yearly, inshore, offshore, alongshore) or ontogenetic (size and stage; pre-, post-, and flexion). Over 130 species of pelagic copepods occur in the area (A. D. McKinnon unpubl.); discrimination of the naupliar and copepodite stages to a higher taxonomic resolution than order (calanoid, cyclopoid, etc.) is logistically difficult in well preserved plankton samples and more so within the guts of larval fish where evidence of the prey is often restricted to pieces of exoskeleton. For these reasons, we have been forced to pool diverse assemblages of organisms into single taxonomic units and to treat these in our analyses in the same way as taxa that we have been able to identify to species. Differences in naupliar behaviour between genera render them differentially susceptible to predation (Titelman \& Kiørboe 2003) and the same is likely to be true for copepodites. Therefore, for any particular family of fish larvae there is an underlying level of prey selection that we have been unable to discriminate. 
Table 3. Density (no. $100 \mathrm{~m}^{-3}$ ) of zooplankton and fish larvae collected by plankton nets at site B near the NWC on 17 February 1999. Hp: harpactocoid copepods, Ca: calanoid copepods, Cy: cyclopoid copepods, NC: non-copepod. Prey items present in guts but not recorded in plankton counts are listed

\begin{tabular}{|c|c|c|}
\hline Taxon & Prey type & Density \\
\hline \multicolumn{3}{|l|}{ Prey } \\
\hline Cyclopoid juveniles $^{\mathrm{a}}$ & & 260000 \\
\hline Bivalves $^{\mathrm{a}}$ & $\mathrm{NC}$ & 99600 \\
\hline Calanoid juveniles & & 94500 \\
\hline Gastropods $^{\mathrm{a}}$ & $\mathrm{NC}$ & 91900 \\
\hline harpacticoid juveniles & & 72400 \\
\hline Larvaceans $^{\mathrm{a}}$ & $\mathrm{NC}$ & 56500 \\
\hline Microsetella sp. & Hр & 26800 \\
\hline Oithona nana $a^{a}$ & $\mathrm{Cy}$ & 18900 \\
\hline Euterpina acutifrons & $\mathrm{Hp}$ & 18900 \\
\hline Chaetognaths ${ }^{\mathrm{a}}$ & NC & 18800 \\
\hline Corycaeus spp. & Cy & 14300 \\
\hline Parvocalanus crassirostris & $\mathrm{Ca}$ & 12600 \\
\hline Oithona attenuata & $\mathrm{Cy}$ & 12600 \\
\hline Oithona simplex & Cy & 9500 \\
\hline Oncaea spp. & $\mathrm{Cy}$ & 6400 \\
\hline Parvocalanus dubia ${ }^{\mathrm{a}}$ & $\mathrm{Ca}$ & 6300 \\
\hline Polychaetes & $\mathrm{NC}$ & 6200 \\
\hline Decapod larvae & $\mathrm{NC}$ & 3200 \\
\hline Oithona spp. & $\mathrm{Cy}$ & 3200 \\
\hline Acartia fossae $e^{a}$ & $\mathrm{Ca}$ & 3100 \\
\hline Canthocalanus pauper ${ }^{a}$ & $\mathrm{Ca}$ & 3100 \\
\hline Euphausid larvae $^{\mathrm{a}}$ & $\mathrm{NC}$ & 3100 \\
\hline Bestiolina similis & $\mathrm{Ca}$ & 1600 \\
\hline Corycaeus dahli & $\mathrm{Cy}$ & 1200 \\
\hline Temora turbinata & $\mathrm{Ca}$ & 1200 \\
\hline Paracalanus indicus ${ }^{\mathrm{a}}$ & $\mathrm{Ca}$ & 900 \\
\hline Acrocalanus gibber ${ }^{a}$ & $\mathrm{Ca}$ & 600 \\
\hline Corycaeus andrewsi & Cy & 600 \\
\hline Clausocalanus farrani & $\mathrm{Ca}$ & - \\
\hline copepod nauplii & & - \\
\hline Corycaeus asiaticus & Cy & - \\
\hline Dynophysis & $\mathrm{NC}$ & - \\
\hline Mite & $\mathrm{NC}$ & - \\
\hline Oithona juveniles & $\mathrm{Cy}$ & - \\
\hline Oithona rigida & Cy & - \\
\hline Parvocalanus sp. & $\mathrm{Ca}$ & - \\
\hline poecilostome juveniles & Cy & - \\
\hline Pseudodiaptomus spp. & $\mathrm{Ca}$ & - \\
\hline \multicolumn{3}{|l|}{ Fish larvae } \\
\hline Callionymidae & & 40 \\
\hline Cynoglossus sp. & & 20 \\
\hline Gobiidae sp. 6 & & 20 \\
\hline Pinguipedidae & & 10 \\
\hline Leiognathidae & & 5 \\
\hline Gobiidae mixed spp. & & 3 \\
\hline Monacanthidae & & 1 \\
\hline Aploactinidae & & 1 \\
\hline Platycephalidae & & 1 \\
\hline Engyspiron sp. & & 0.5 \\
\hline Carangidae & & 0.5 \\
\hline Samaridae & & 0.2 \\
\hline Opistognathidae & & 0.2 \\
\hline
\end{tabular}

\section{Inter-specific differences within families}

Dietary information is available for at least 7 species of scombrids and 9 species of bothids (Uotani et al. 1981, Jenkins et al. 1984, Young \& Davis 1990, this study). This limited database suggests that interspecific differences are no greater than inter-family differences in diet. We could not identify the scombrids in our study confidently to genus but they all appeared to be representatives of one species. These larvae were mostly $\sim 5 \mathrm{~mm}$ and ate copepod nauplii and appendicularians, which is consistent with the findings of other studies (see Table 4). Auxis spp., Scomberomorus spp., and Katsuwonus spp. larvae examined in three different studies (Uotani et al. 1981, Jenkins et al. 1984, Young \& Davis 1990) all showed a preference for appendicularians when less than $5.5 \mathrm{~mm}$ long, with only Thunnus spp. showing a preference for copepod nauplii and cladocerans (Evadne spp.) at a similar size. Bothids also ate appendicularians and calanoid copepods, with some species eating both of these prey items and others preferring only one. Variation in diet among species within a family was recorded in our study where one goby (goby 6) showed slightly different prey preference to other co-occurring gobiid species. All of these larvae showed strong preference for Bestiolina similis, but goby 6 ate polychaetes, Euterpina acutifrons and Corycaeus sp., in contrast to the remaining species that ate Oithona nana and $O$. attenuata. Such differences in prey choices within families may be related to differences in encounter rates between larvae and prey, which will be affected by prey patchiness (Jenkins 1988) and small scale turbulence (Gallego et al. 1996, MacKenzie \& Kiørboe 2000) and may also be affected by variation in the morphology, physiology and behaviour among species within a family. However, the consistency of prey choices across families collected at different locations and times suggests that prey selection by fish larvae is influenced by characteristics of their prey and the inherent preferences of particular taxa.

\section{Prey characteristics - copepod prey}

The characteristics of copepods as prey for larval fishes differed between and within orders. Some families of fishes preferred calanoid copepods, others ate more cyclopoid copepods (including species in the families Oncaeidae, Corycaeidae and Oithonidae; Boxshall \& Halsey 2004). These prey types have very different characteristics, with Oithona spp. being small, cryptic (clear) with a strong escape response thus rendering them less susceptible to visual preda- 


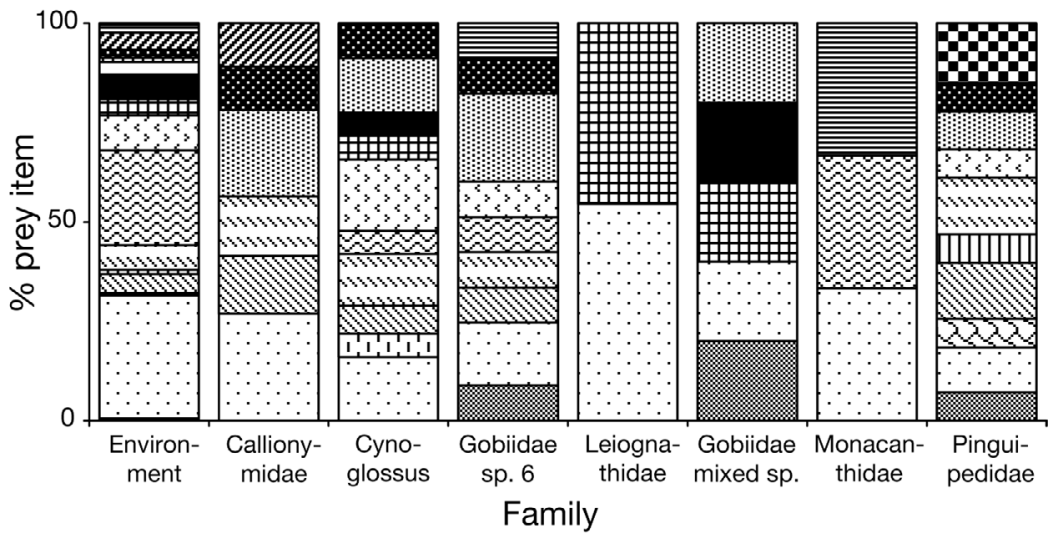

\begin{tabular}{|c|c|}
\hline 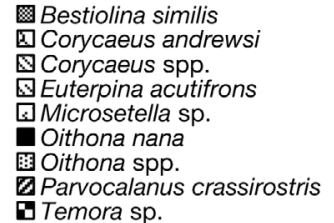 & 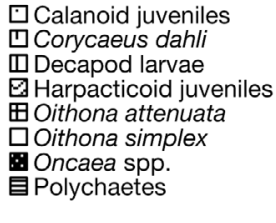 \\
\hline
\end{tabular}

Fig. 4. Composition of prey items in the zooplankton community ('Environment') compared to that found within the guts of larvae of tropical shore fishes collected by plankton nets near the NWC

tion when compared to many of the calanoid copepods such as Centropages spp., Paracalanus sp., Pseudocalanus sp., and Calanus spp., which are slower moving, larger and sometimes pigmented (Kimmerer 1991). Small calanoids of the genera Clausocalanus, Pseudodiaptomus, Canthocalanus, Calanopia, Temora, Paracalanus, Parvocalanus and Bestiolina were greatly favoured by the fish larvae we examined. These may

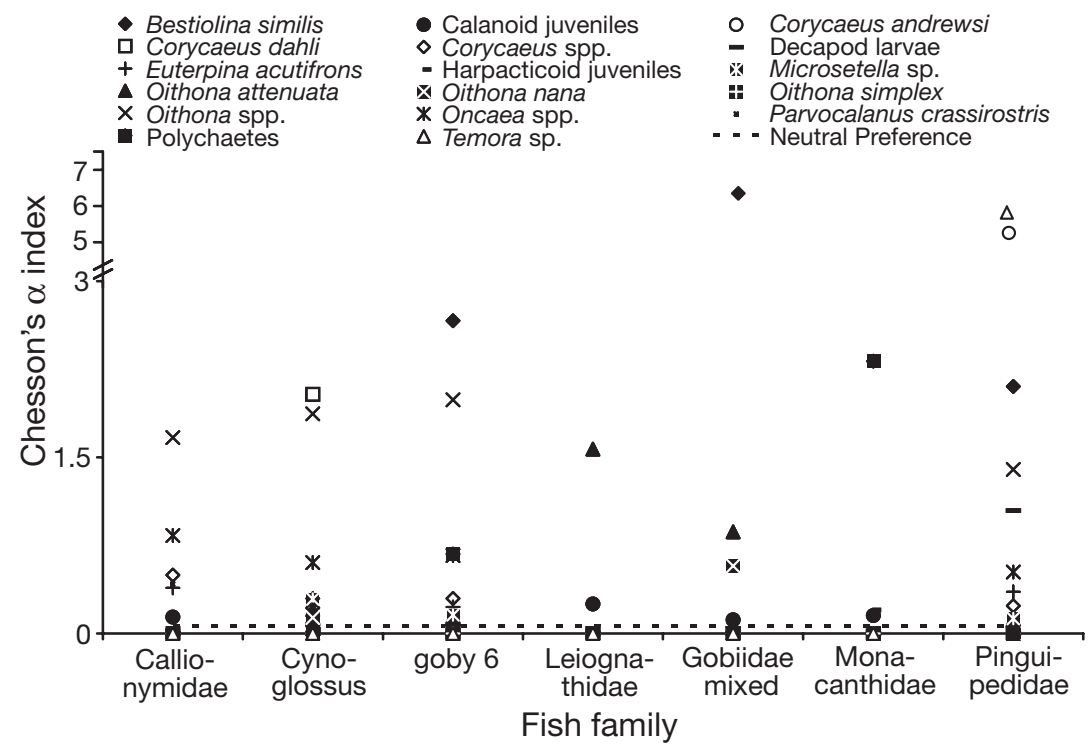

Fig. 5. Prey selectivity values (Chesson's $\alpha$ index) for 7 co-occurring taxa of larval fishes collected in a single plankton net near the NWC tors, they may in turn be predictably high in nutritional content. Preferential selection of calanoid copepods has been recorded in both temperate (Pepin \& Penney 1997) and tropical environments (Mitchell 1991) when prey was not limited. In aquarium trials of laboratory-reared larvae fed different concentrations of field-captured zooplankton, two species of pomacentrids, Amphiprion polymnus and Amblyglyphidodon aureus showed positive selection for calanoid species and negative selection for oithonid copepods, despite the higher numbers of oithonids in the plankton offered (Mitchell 1991). We provide further support for this interpretation as $85 \%$ of families examined (i.e. 40 of 47 with prey in the guts) contained calanoid copepods and for $43 \%$ of these families, calanoids constituted $>50 \%$ of their diet. In comparison, $72 \%$ of the families fed on oithonid prey but only in $6 \%$ of the cases did oithonids form $>50 \%$ of the diet. Thus, it appears that larval fishes in the tropics will preferentially select calanoid copepods as prey.

\section{Prey characteristics - non-copepod prey}

Mollusc veligers, chaetognaths, appendicularians and protists were only eaten 
Table 4. Comparison of diets for selected families from our study with the results from previous studies. Since the diets of larval fishes alter with size (Østergaard et al. 2005), the data are limited to tropical larvae with dietary information for larvae of similar sizes to those sampled in our study. Only dominant prey items are listed. $\mathrm{N}=$ no. of individuals examined

\begin{tabular}{|c|c|c|c|c|}
\hline Taxa & $\mathrm{N}$ & Location & Diet & Source \\
\hline \multicolumn{5}{|l|}{ Clupeidae } \\
\hline Mixed species & 392 & Florida & Copepods & Houde \& Lovdal 1984 \\
\hline Unidentified species & 20 & NW Shelf & Calanoid copepods & Present study \\
\hline \multicolumn{5}{|l|}{ Callionymidae } \\
\hline Callionymus decoratus & 17 & Hawaii & Cyclopoid copepods probably Oithona & Watson 1974 \\
\hline Callionymus pauciradiatus & 770 & Florida & Copepod nauplii & Houde \& Lovdal 1984 \\
\hline Unidentified species & 21 & NW Shelf & Harpacticoid, cyclopoid (Oithona) copepods & Present study \\
\hline \multicolumn{5}{|l|}{ Scorpaenidae } \\
\hline Scorpaenodes sp. & 89 & Andaman Sea & Calanoid, corycaeid, oncaeid copepods & Østergaard et al. 2005 \\
\hline Unidentified species & 10 & NW Shelf & Calanoid, oithonid, corycaeid copepods & Present study \\
\hline \multicolumn{5}{|l|}{ Acanthuridae } \\
\hline Acanthurus triostegus & 3 & Hawaii & Appendicularians, larval polychaete & Randall 1961 \\
\hline Unidentified species & 1 & NW Shelf & Appendicularians & Present study \\
\hline \multicolumn{5}{|l|}{ Apogonidae } \\
\hline Foa brachygrammus & 34 & Hawaii & Tintinnids & Watson 1974 \\
\hline Unidentified species & 130 & Florida & Copepods & Houde \& Lovdal 1984 \\
\hline Unidentified species & 10 & NW Shelf & Copepod juveniles, calanoids & Present study \\
\hline \multicolumn{5}{|l|}{ Blennidae } \\
\hline Omobranchus elongatus & 15 & Hawaii & Copepods & Watson 1974 \\
\hline Blennius sp. & 4 & Hawaii & Tintinnids & Watson 1974 \\
\hline Unidentified species & 10 & NW Shelf & Corycaeid, oithonid copepods, bivalves & Present study \\
\hline \multicolumn{5}{|l|}{ Carangidae } \\
\hline Atule (Caranx) mate & 48 & Hawaii & Cyclopoid copepods probably Oithona & Watson 1974 \\
\hline Carangoides & 80 & Andaman Sea & Oncaeid, corycaeid, calanoid copepods & Østergaard et al. 2005 \\
\hline Unidentified species & 3 & NW Shelf & Copepod nauplii, calanoid copepods & Present study \\
\hline \multicolumn{5}{|l|}{ Gobiidae } \\
\hline Unidentified species & 525 & Florida & Copepod nauplii, bivalves, tintinnids & Houde \& Lovdal 1984 \\
\hline Mixed species & 39 & NW Shelf & Copepods & Present study \\
\hline \multicolumn{5}{|l|}{ Haemulidae } \\
\hline Orthopristus chrysoptera & 242 & Florida & Copepods & Houde \& Lovdal 1984 \\
\hline Unidentified species & 12 & NW Shelf & Oithonid copepods & Present study \\
\hline \multicolumn{5}{|l|}{ Pomacentridae } \\
\hline Abudefduf abdominalis & 3 & Hawaii & Tintinnids at $<3 \mathrm{~mm} \mathrm{SL}$, copepods $>3 \mathrm{~mm}$ & Watson 1974 \\
\hline Amblyglyphidodon aureus & & PNG & Calanoid \& oithonid copepods & Mitchell 1991 \\
\hline Amphiprion polymnus & & PNG & Calanoid \& oithonid copepods & Mitchell 1991 \\
\hline \multicolumn{4}{|l|}{ Scaridae } & Present study \\
\hline Scomberomorus semifasciatus & 90 & GBR & Fish larvae & Scombridae \\
\hline Scomberomorus queenslandicus & 181 & GBR & Appendicularians, fish larvae & Jenkins et al. 1984 \\
\hline Scomberomorus commerson & 51 & GBR & Appendicularians, fish larvae & Jenkins et al. 1984 \\
\hline Thunnus spp. & $1000+$ & Indian Ocean & Coryceus sp., Evadne sp. & \\
\hline Katsuwonus pelamis & $300+$ & Indian Ocean & Appendicularians, fish larvae & $\begin{array}{l}\text { Uotanl et al. } 1981 \\
\text { Uotani et al. } 1981\end{array}$ \\
\hline Auxis spp. & $300+$ & Indian Ocean & Appendicularians, Evadne sp. & Uotani et al. 1981 \\
\hline Thunnus macoiyi & 583 & Indian Ocean & Calanoid, cyclopoid, copepod nauplii, Evadne & Young \& Davis 1990 \\
\hline Thunnus alalunga & 275 & Indian Ocean & Coryceus, Farannula gibber, copepod nauplii & Young \& Davis 1990 \\
\hline Katsuwonus pelamis & 65 & Indian Ocean & Appendicularians, calanoids, nauplii, fish larvae & Young \& Davis 1990 \\
\hline Unidentified sp. & 20 & NW Shelf & Copepod nauplii, appendicularians & Present study \\
\hline \multicolumn{5}{|l|}{ Bothidae } \\
\hline Psettodes erumei & 11 & GBR & Copepods & Liew 1983 \\
\hline Pseudorhombus arsius & 34 & GBR & Appendicularians, copepods & Liew 1983 \\
\hline Pseudorhombus elevatus & 28 & GBR & Copepods & Liew 1983 \\
\hline Pseudorhombus spinosus & 28 & GBR & Copepods, appendicularians, chaetognaths & Liew 1983 \\
\hline Pseudorhombus diplospilus & 28 & GBR & Appendicularians, chaetognaths & Liew 1983 \\
\hline Grammatobothus spp. & 46 & GBR & Paracalanid copepods & Liew 1983 \\
\hline Engyprosopon grandisquama & 24 & GBR & Appendicularians & Liew 1983 \\
\hline Asterorhombus intermedius & 26 & GBR & Appendicularians & Liew 1983 \\
\hline Unidentified species & 20 & NW Shelf & Appendicularians, calanoid copepods & Present study \\
\hline \multicolumn{5}{|l|}{ Cynoglossidae } \\
\hline Cynoglossus sp. & 32 & Andaman Sea & Harpacticoid, oncaeid, copepod nauplii & Østergaard et al. 2005 \\
\hline Cynoglossus sp. & 20 & NW Shelf & Calanoid, cycloipod, oncaeid copepods & Present study \\
\hline
\end{tabular}


by a small number of fish families, but when consumed they were often a preferred prey. Mollusc veligers are highly visible and slow moving but their shell may make them harder to digest and thus limit their desirability as prey. Tetraodontids were the only larvae to consume mollusc veligers as a major part of their diet in this study, whereas blennids, siganids and labrids ate mollusc veligers as only a minor part of the diet. Chaetognaths are ambush predators (Kimmerer 1991) and have been known to eat larval fishes (Hunter 1981), although their main diet is copepods (Alvarez Cadena 1993). They are preyed upon by larval fishes (Hunter 1981) but generally do not form a major component of their diet. Larvae of 3 families of tropical fishes are known to utilise chaetognaths as prey: chaetodontids (this study), scombrids (Young \& Davis 1990) and bothids (Liew 1983). Appendicularians are long, thin, softbodied tunicates of limited mobility, which are encased in a mucus house and as a result may be difficult for many larvae to detect and capture (Liew 1983). These were also only eaten by a small number of families including scombrids (Uotani et al. 1981, Jenkins et al. 1984, Young \& Davis 1990, this study), bothids (Liew 1983, this study), and acanthurids (Randall 1961, this study). Mollusc veligers, chaetognaths and appendicularians are not predated by many families of fish larvae, implying that specialised physiological and morphological adaptations are required for these prey types. Laboratory experiments to determine the ability of larvae to handle different prey types would advance our understanding of larval fish life history strategies and food webs in tropical environments.

\section{Larval fish feeding and pelagic food webs on the North West Shelf of Australia}

During the period of our study the waters of the North West Shelf of Australia had intermittently high primary production, particularly during the 1997-98 El Niño event (Furnas 2007). The concurrent study of Meekan et al. (2003) found differences in both ambient temperature and zooplankton biomass between years, with the summer of 1997-98 characterised by cooler water temperatures, higher concentrations of chlorophyll $a$ and higher zooplankton biomass. The composition of the larval fish community also varied between these years (Sampey et al. 2004). For example, carangids were more abundant in 1997-98 than in 1998-99, and increased in abundance during the summer of 1997-98 (Sampey et al. 2004); a pattern mirrored by the small calanoids (McKinnon \& Duggan 2003) predominant in their diet. The small calanoid prey fraction were severely food-limited during the period of this study (McKinnon \& Duggan 2003), as were the adults of the paracalanid copepods important amongst the small calanoid fraction (McKinnon \& Duggan 2001). Food limitation of copepod growth appears to generally be the case in tropical shelf environments (McKinnon \& Duggan 2003). Subsequent low transfer efficiencies through the phytoplankton-copepod-larval fish food chain may therefore contribute to food limitation of the components of the larval fish community dependant on copepod prey.

Protists have generally been neglected or underestimated as potential prey items in investigations of larval fish diets either due to the specific methodology required to identify them or because they have already been digested (de Figueiredo et al. 2005). Some taxa of larval fishes in the area can feed directly on the protist community (see diets of callionymids, monacanthids and tetraodontids) and others may link into the microbial food web through other prey items such as appendicularia (scombrids, bothids and acanthurids), polychaetes (lethrinids, monacanthids and gobiids) and molluscs (tetraodontids, blennids, labrids, siganids and monacanthids). However, generally protistan microzooplankton on the NWS appear unlikely to be important in the transfer of energy to larval fishes since they consume $<5 \%$ of primary production (Moritz et al. 2006). Engraulids and scarids (amongst others) were recorded as having empty guts, but this may only reflect the absence of the more easily identified metazoans in their guts and these families could conceivably have been feeding on delicate micro-organisms such as ciliates. An ability to feed either directly or indirectly (e.g. via picoplankton grazers such as appendicularia) on components of the microbial food web might explain why the larvae of some reef fishes such as acanthurids, chaetodontids and labrids are frequently found offshore, 100s of $\mathrm{km}$ from land, whereas others such as most pomacentrids are rarely captured in oceanic waters (Victor 1987, Clarke 1995, Mora 2002, Lo Yat et al. 2006). However, our results, although intriguing and consistent with those of other studies (e.g. acanthurids, Randall 1961) are based on the analysis of only a few individuals. Confirmation of these ideas will require targeted sampling of larval reef fishes on broad cross-shelf and oceanic transects. The development of molecular probes to identify gut contents (e.g. Nejstgaard et al. 2003, Suzuki et al. 2006) represents a powerful new tool to quantify predation on protists and other easily digested organisms. Such tools will be necessary to fully appreciate the diversity of larval fish diets.

\section{CONCLUSIONS}

Our aim was to provide some insight into the feeding of as many taxa as possible of tropical fish larvae. Dietary preferences were broadly similar to those 
found in studies of fish larvae from temperate ecosystems. Despite the limited numbers of individuals examined in some families, there were clear differences between families of larval fish in prey types eaten. Most families of larval fish preferred copepod prey, and only 4 families were restricted to non-copepod prey. Calanoid rather than cyclopoid copepods were the preferred prey of most families of fish larvae, possibly because of their size, pigmentation, escape responses and nutritional value, and some calanoid genera (e.g. Bestiolina) were preferred prey items. Comparison of our data with studies of fish from the same families found elsewhere indicates that there are inter-specific differences in dietary preference. The selectivity displayed by fish larvae specialising on copepods reinforces the value of identifying prey to a low taxonomic level and highlights the need to develop more powerful tools towards this end. The ability of fish larvae to access components of the microbial food webs predominant in tropical waters is likely to determine their differential feeding success and subsequent distribution within the plankton.

Acknowledgements. We thank the numerous volunteers, students and crew of the RV 'Lady Basten' who aided in the field work for this study; S. Duggan for sorting the zooplankton samples used in the prey selectivity analyses; J. Leis and T. Trnski (Australian Museum), V. Bates (AIMS) and M. Kingsford (JCU), who aided in identifying fishes; J. Carleton (AIMS) gave statistical advice; D. Gaughan (WA Fisheries) for a discussion about prey selectivity indices; T. Lemberget (JCU) for comments on this manuscript; and P. Doherty (AIMS), whose ideas initially triggered this work and who also provided helpful comments on the manuscript. Thanks to J. Leis (Australian Museum), P. Munk (Danish Institute for Fisheries Research) and 2 anonymous reviewers whose comments improved this manuscript.

\section{LITERATURE CITED}

Alvarez Cadena J (1993) Feeding of the chaetognath Sagitta elegans Verill. Estuar Coast Shelf Sci 36:195-206

Arthur DK (1976) Food and feeding of larvae of three fishes occurring in the California Current, Sardinops sagax, Engraulis mordax, and Trachurus symmetricus. Fish Bull 74:517-530

Blaxter JHS (1986) Development of sense organs and behaviour of teleost larvae with special reference to feeding and predator avoidance. Trans Am Fish Soc 115:98-114

Boxshall GA, Halsey SH (2004) An introduction to copepod diversity. The Ray Society, London

Chesson J (1978) Measuring preference in selective predation. Ecol 59:211-215

Clarke KR, Warwick RM (2000) Change in marine communities: an approach to statistical analysis and interpretation. Plymouth Marine Laboratory, Plymouth, UK

Clarke TA (1995) Larvae of near-shore fishes in oceanic waters of the central equatorial Pacific. Pac Sci 49:134-142

de Figueiredo GM, Nash RDM, Montagnes DJS (2005) The role of the generally unrecognised microprey source as food for larval fish in the Irish Sea. Mar Biol 148:395-404
Fisher R, Bellwood DR (2001) Effects of feeding on the sustained swimming abilities of late-stage larval Amphiprion melanopus. Coral Reefs 20:151-154

Fisher R, Bellwood DR, Job SD (2000) Development of the swimming abilities in reef fish larvae. Mar Ecol Prog Ser 202:163-173

Fuiman LA, Higgs DM (1997) Ontogeny, growth and the recruitment process. In: Chambers RC, Trippel EA (eds) Early life history and recruitment in fish populations. Chapman \& Hall, London, p 225-249

Furnas MJ (2007) Intra-seasonal and inter-annual variations in phytoplankton biomass, primary production and bacterial production at North West Cape, Western Australia; links to the 1997-98 El Niño event. Cont Shelf Res 27: 958-980

Gallego A, Heath MR, McKenzie E, Cargill LH (1996) Environmentally induced short-term variability in the growth rates of larval herring. Mar Ecol Prog Ser 137:11-23

Hjort J (1914) Fluctuations in the great fisheries of northern Europe viewed in the light of biological research. Rapp P-V Reun Cons Int Explor Mer 20:1-228

Houde ED (1987) Fish early life dynamics and recruitment variability. Am Fish Soc Symp 2:17-29

Houde ED, Lovdal JA (1984) Seasonality of occurrence, foods and food preferences of ichthyoplankton in Biscayne Bay, Florida. Estuar Coast Shelf Sci 18:403-419

Hunter J (1981) Feeding ecology and predation of marine fish larvae. In: Lasker R (ed) Marine fish larvae: morphology, ecology, and relation to fisheries. University of Washington Press, Seattle, WA, p 33-77

Jenkins GP (1988) Micro- and fine-scale distribution of microplankton in the feeding environment of larval flounder. Mar Ecol Prog Ser 43:233-244

Jenkins GP, Milward NE, Hartwick RF (1984) Food of larvae of Spanish mackerals, genus Scomberomorus (Teleostei: Scombridae), in shelf waters of the Great Barrier Reef. Aust J Mar Freshw Res 35:477-482

Kimmerer WJ (1991) Predatory influences on copepod distributions in coastal waters. Proceedings of the Fourth International Conference on Copepoda. Bull Plankton Soc Japan Spec Vol, 161-174

Kleppel GS, Burkart CA (1995) Egg production and the nutritional environment of Acartia tonsa: the role of food quality in copepod nutrition. ICES J Mar Sci 52:297-304

Last JM (1980) The food of twenty species of fish larvae in the west-central North Sea. Fish Res Tech Rep Dir Fish Res 60

Leis JM (1991) The pelagic stage of reef fishes. In: Sale PF (ed) The ecology of fishes on coral reefs. Academic Press, San Diego, CA, p 183-230

Leis JM (1993) Larval fish assemblages near Indo-Pacific coral reefs. Bull Mar Sci 53:362-392

Leis JM, Carson-Ewart BM (1999) In situ swimming and settlement behaviour of larvae of an Indo-Pacific coral-reef fish, the coral trout Plectropomus leopardus (Pisces: Serranidae). Mar Biol 134:51-64

Leis JM, Carson-Ewart BM (2000) The larvae of Indo-Pacific coastal fishes: an identification guide to marine fish larvae. Brill, Leiden

Leis JM, McCormick MI (2002) The biology, behaviour, and ecology of the pelagic, larval stage of coral reef fishes. In: Sale PF (ed) Coral reef fishes. Elsevier Science, New York, p 171-199

Leis JM, Sweatman HPA, Reader SE (1996) What are pelagic stages of coral reef fishes doing out in blue water: daytime field observations of larval behavioural capabilities. Mar Freshw Res 47:401-411 
Liew HC (1983) Studies on flatfish larvae (Fam. Psettodidae and Bothidae, Pleuronectiformes) in the shelf waters of the Central Great Barrier Reef, Australia. MSc thesis, James Cook University of North Queensland, Townsville

Lowe-McConnell RH (1987) Ecological studies in tropical fish communities. Cambridge University Press, Cambridge

Lo-Yat A, Meekan MG, Carleton JH, Galzin R (2006) Largescale dispersal of the larvae of nearshore and pelagic fishes in the tropical oceanic waters of French Polynesia. Mar Ecol Prog Ser 325:195-203

MacKenzie BR, Kiørboe T (2000) Larval fish feeding and turbulence: a case for the downside. Limnol Oceanogr 45: $1-10$

McKinnon AD, Duggan S (2001) Summer egg production rates of paracalanid copepods in subtropical waters adjacent to Australia's North West Cape. Hydrobiologia 453454:121-132.

McKinnon AD, Duggan S (2003) Summer copepod production in subtropical waters adjacent to Australia's North West Cape. Mar Biol 143:897-907

McKinnon AD, Trott LA, Cappo M, Miller DK, Duggan S, Speare P, Davidson A (2002) The trophic fate of shrimp farm effluent in mangrove creeks of North Queensland, Australia. Estuar Coast Shelf Sci 55:655-671

McKinnon AD, Duggan S, Nichols PD, Rimmer MA, Semmens G, Robino B (2003) The potential of tropical paracalanid copepods as live feeds in aquaculture. Aquaculture 223: 89-106

McLaren IA, Avendano P (1995) Prey field and diet of larval cod on Western Bank, Scotian Shelf. Can J Fish Aquat Sci 52:448-463

McLaren IA, Avendano P, Taggart CT, Lochman SE (1997) Feeding by larval cod in different water-masses on Western Bank, Scotian Shelf. Fish Oceanogr 6:250-265

Meekan MG, Carleton JH, McKinnon AD, Flynn K, Furnas M (2003) What determines the growth of tropical reef fish larvae in the plankton: food or temperature? Mar Ecol Prog Ser 256:193-204

Mitchell AW (1991) Dietary investigations of coral reef fish larvae. MPhil thesis, Griffith University, Nathan

Mora C, Sale PF (2002) Are populations of coral reef fish open or closed? Trends Ecol Evol 17:422-428

Moritz CM, Montagnes DJS, Carleton JH, Wilson D, McKinnon AD (2006) The potential role of microzooplankton in

Editorial responsibility: Otto Kinne (Editor-in-Chief), Oldendorf/Luhe, Germany a northwestern Australian pelagic food web. Mar Biol Res 2:1-13

Nejstgaard JC, Frischer ME, Raule CL, Gruebel R, Kohlberg KE, Verity PG (2003) Molecular detection of algal prey in copepod guts and fecal pellets. Limnol Oceanogr Methods 1:29-38

Ohta I, Tachihara K (2004) Larval development and food habits of the marbled parrotfish, Leptoscarus vaigiensis, associated with drifting algae. Ichthyol Res 51:63-69

Østergaard P, Munk P, Janekarn V (2005) Contrasting feeding patterns among species of fish larvae from the tropical Andaman Sea. Mar Biol 146:595-606

Pepin P, Penney RW (1997) Patterns of prey size and taxonomic composition in larval fish: are there general sizedependent models? J Fish Biol 51:84-100

Randall JE (1961) A contribution to the biology of the convict surgeonfish of the Hawaiian Islands, Acanthurus triostegus sandvicensis. Pac Sci 15:215-272

Sampey A, Meekan MG, McKinnon AD, Carleton JH, McCormick MI (2004) Temporal patterns in distributions of tropical fish larvae on the North-west Shelf of Australia. Mar Freshw Res 55:473-487

Sassa C, Kawaguchi K (2004) Larval feeding habits of Diaphus garmani and Myctophum asperum (Pisces: Myctophidae) in the transition region of the western North Pacific. Mar Ecol Prog Ser 278:279-290

Suzuki N, Murakami K, Takeyama H, Chow S (2006) Molecular attempt to identify prey organisms of lobster phyllosoma larvae. Fish Sci 72:342-349

Titelman J, Kiørboe T (2003) Predator avoidance by nauplii. Mar Ecol Prog Ser 247:137-149

Uotani I, Matsuzaki K, Makino Y, Noda K, Inamura O, Horikawa M (1981) Food habits of larvae of tunas and their related species in the area northwest of Australia. Bull Jpn Soc Sci Fish 47:1165-1172

Victor BC (1987) Growth, dispersal, and identification of planktonic labrid and pomacentrid reef-fish larvae in the eastern Pacific Ocean. Mar Biol 95:145-152

Watson W (1974) Diel changes in the vertical distributions of some common fish larvae in southern Kaneohe Bay, Oahu, Hawaii. MSc thesis, University of Hawaii, Honolulu, HI

Young JW, Davis TLO (1990) Feeding ecology of larvae of southern bluefin, albacore and skipjack tunas (Pisces: Scombridae). Mar Ecol Prog Ser 61:17-29

Submitted: June 7, 2006; Accepted: November 1, 2006 Proofs received from author(s): May 11, 2007 